\title{
EFFECT OF KILN TEMPERATURE AND TYPE OF WOOD ON CHARCOAL QUALITY
}

\author{
M. A. Orabi' ${ }^{1}$ A. H. Bahnasawy ${ }^{2}$, S. A. Ali ${ }^{2}$, T. H. Ashour ${ }^{2}$ and I. Yehia ${ }^{3}$
}

${ }^{1}$ Assist. Res., Ag. Operations Mechanization Systems Dept., Ag. Eng. Res. Inst., Giza, Egypt.

${ }^{2}$ Prof. of Ag. Eng., Ag. and Bio Systems Eng. Dept. Fac. of Ag., Benha U., Moshtohor, Egypt.

${ }^{3}$ Head of Res., Ag. Operations Mechanization Systems Dept., Ag. Eng. Res. Inst., Giza, Egypt.

*E-mail: orabi50@yahoo.com

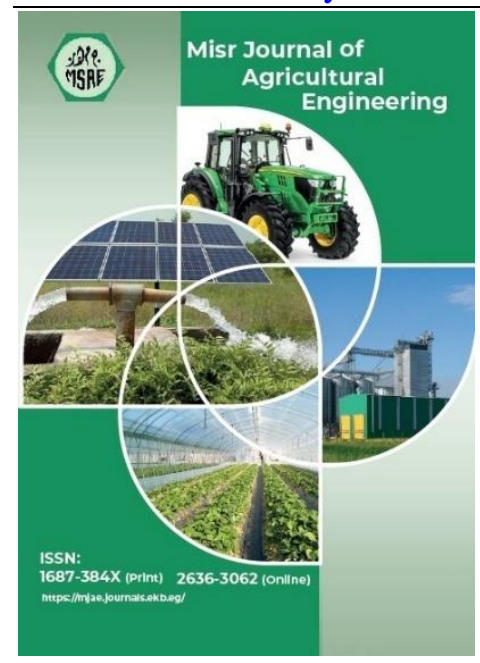

(C) Misr J. Ag. Eng. (MJAE)

\section{Keywords:}

Carbonization, charcoal quality, wood moisturecontent, citrus branches, casuarina wood, emission treatment

\section{ABSTRACT}

The aim of this study is to investigate the effect of kiln temperature and type of wood on charcoal quality. The studied factors are two types of wood "casuarina and citrus", moisture-contents of 6.8 and $7 \%(\mathrm{db})$ respectively and pyrolysis temperatures of 573.15 , $623.15,673.15$ and $723.15 \mathrm{~K}$. The main results in this study can be summarized in the following points: The maximum moisturecontent of $5.52 \%$ was obtained using casuarina wood at kiln temperature of $723.15 \mathrm{~K}$. Meanwhile, the minimum moisturecontent of $1.28 \%$ was obtained using citrus branches at kiln temperature of $573.15 \mathrm{~K}$. The maximum ash-content of charcoal of $11.26 \%$ was obtained using casuarina wood at kiln temperature of $573.15 \mathrm{~K}$. Meanwhile, the minimum ash-content of charcoal of $4.95 \%$ was obtained using citrus branches at kiln temperature of $723.15 \mathrm{~K}$. The maximum volatile-matter of 21.25 $\%$ was obtained using citrus charcoal at kiln temperature of $573.15 \mathrm{~K}$. Moreover, the minimum volatile-matter of charcoal of $4.13 \%$ was obtained using casuarina charcoal at kiln temperature of $723.15 \mathrm{~K}$. The maximum fixed-carbon of charcoal of $84.81 \%$ was obtained using citrus branches at kiln temperature of $723.15 \mathrm{~K}$. Meanwhile, the minimum fixed-carbon of charcoal of $65.13 \%$ was obtained using casuarina at kiln temperature of $573.15 \mathrm{~K}$. The maximum heating value of citrus charcoal of $31703 \mathrm{~kJ} . \mathrm{kg}-1$ was obtained at kiln temperature of $723.15 \mathrm{~K}$. Moreover, the minimum heating value of casuarina charcoal of $28004 \mathrm{~kJ} . \mathrm{kg}-1$ was obtained at kiln temperature of $573.15 \mathrm{~K}$.

\section{INTRODUCTION}

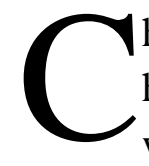
harcoal is a popular household fuel in many parts of the developing countries. Charcoal has been an important domestic product for many years and regardless of how produced with market acceptance. The greatest uses of charcoal are for home and outdoor recreational cooking. Charcoal also used in the production of carbon disulfide, carbon tetrachloride, sodium cyanide and other industrial chemicals. Extensive amounts converted to 
activated carbons. Other industrial uses are in connection with steel heating, nonferrous smelting and metal case hardening.

Biomass is the third largest energy resource in the world. Biomass is a renewable resource that provided steady and abundant supply of waste materials such as empty fruit branches, wood chips, and casuarina wood. These waste materials traditionally used for the production of charcoal and carbon materials including the porous structure activated carbons and microporous amorphous carbon materials that are widely used as adsorbents (Bapat et al., 1997).

Charcoal is a solid bio fuel obtained from biomass by means of a chemical process known as "pyrolysis" or simply as "carbonization process". Charcoal consists of the thermal decomposition of biomass in the absence of oxygen. The first source of human energy is wood fuel. (Hosier ,1993).

John et al. (2017) reported that the charcoal could use for industrial fuel, cooking fuel, fireworks, carbon source, filtration and filtration, art and medicine.

Egypt produces 1.3 million $\mathrm{Mg}$ of charcoal annually, of which $99 \%$ is used by domestic consumers for cooking and household heating. Egypt exported about 20 - 50 thousand $\mathrm{Mg}$ of charcoal. Gomaa et al. (2011).

Vandam (2014) said that the use of charcoal as energy inputs is secular and widespread, and is the only source of energy for a large part of the world's population, as in many African countries produce more than $60 \%$ of world charcoal-production. Kaale (2005) found that charcoal has a higher thermal value per unit weight of firewood of about $31.8 \mathrm{MJ}_{\mathrm{kg}}{ }^{-1}$ of fully carbonized

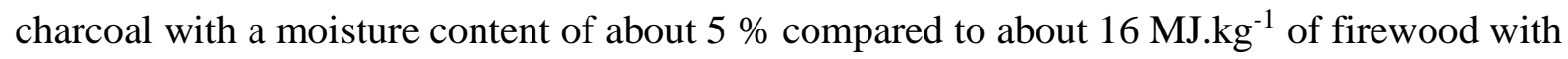
moisture content of about $15 \%$ on a dry basis. Keita (2010) found that the value of wood heating in general is about $3500 \mathrm{kcal} . \mathrm{kg}^{-1}$ for green wood and $4500-4770 \mathrm{kcal} . \mathrm{kg}^{-1}$ for dry wood. The heating value of charcoal is near $7500 \mathrm{kcal}^{\mathrm{kg}} \mathrm{kg}^{-1}$.

The objectives of this research are to investigate the following points:

(1) Studying the effect of kiln temperature on charcoal quality (moisture content, ash content, fixed carbon, bulk density, volatile matter and calorific value).

(2) Studying the effect of casuarina wood and citrus branches on charcoal quality.

\section{2- MATERIALS AND METHODS}

\section{2-1: Materials:}

\section{2-1-1: Charcoal production-unit:}

Charcoal production-unit which designed by "Orabi et al., 2020" was used in this research to produce the charcoal. The tested kiln consists of control unit, fire chamber, treatment unit, and carbonization chamber. Fig. 1 shows a photograph of the tested kiln.

\section{2-1-2: Ceramic oven.}

Ceramic oven was designed to determine the properties of charcoal quality (ash content, fixed carbon, volatile matter and calorific value). The ceramic oven consists of the following parts:

\section{(a) The furnace unit.}

Overall dimensions of the furnace unit were $50 \times 50 \times 40 \mathrm{~cm}$. The furnace unit consists of 6 layers. The first layer was an iron sheet with thickness of $3 \mathrm{~mm}$. The second layer was thermal brick with thickness of $20 \mathrm{~mm}$. The third layer was a rock wool with thickness of $100 \mathrm{~mm}$. The fourth layer was an iron sheet with thickness of $3 \mathrm{~mm}$. The fifth layer was a 
ceramic fiber with thickness of $20 \mathrm{~mm}$. The sixth layer was thermal brick with thickness of 20 $\mathrm{mm}$. The heater was put inside the sixth layer. There is a ventilation square-hole with dimensions of $10 \times 10 \mathrm{~mm}$, sensor hole with diameter $8 \mathrm{~mm}$ and two holes with diameter of 8 $\mathrm{mm}$ for heater cables in middle of the back of furnace unit. Figs. From $r$ to $\leqslant$ show photograph, isometric and views of the ceramic oven.

(b) Control unit.

Control unit used to control of temperatures of kiln and ceramic oven. Fig. 5 shows photograph of the control unit. The control unit consists of thermometer, button, alarm, heater lamp, motor lamp and power lamp.

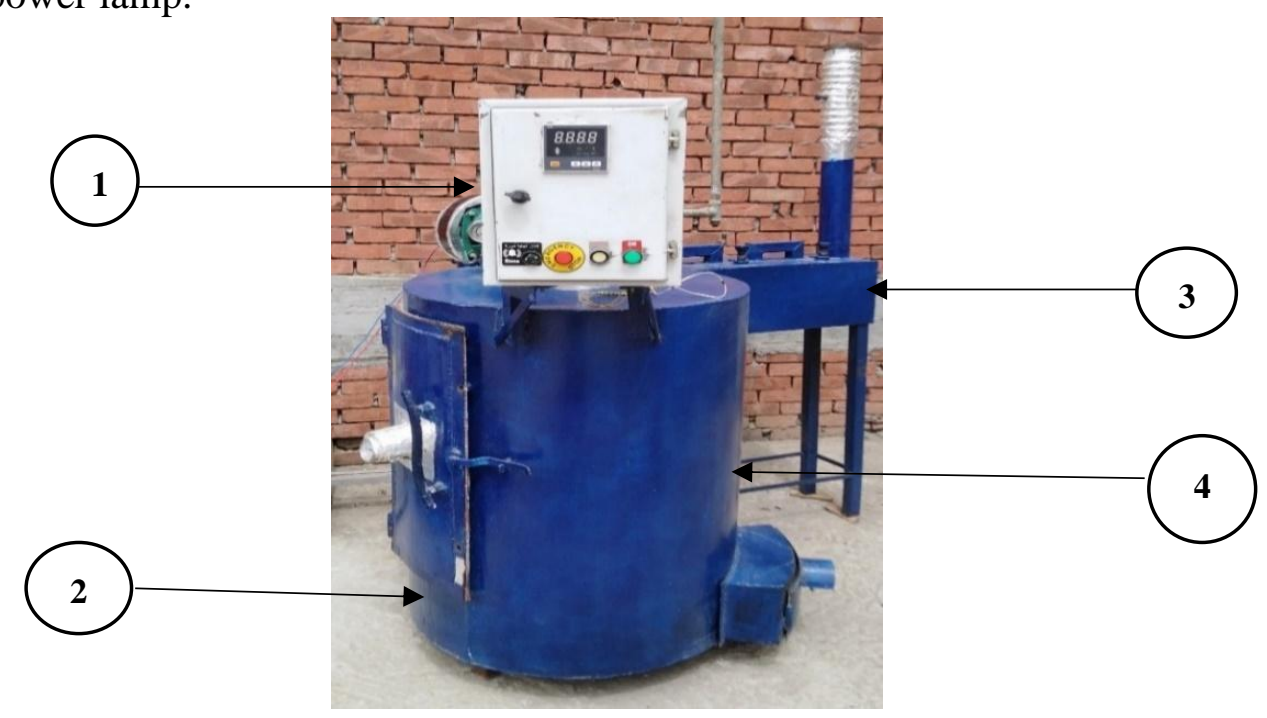

(1) Control unit, (2) fire chamber, (3) treatment unit and (4) carbonization chamber.

Fig. 1: Photograph of charcoal production-unit (Orabi et al, 2020).

\section{2-1-3: Electrical oven.}

Electrical oven was used to dry of wood samples and determine moisture content of wood and charcoal according to ASAE Standard "S353 DEC97, 1998 and AOAC, 1990". The wood samples dried at $378.15 \mathrm{~K}$ for $24 \mathrm{~h}$ or until a constant mass and charcoal sample dried at 378.15 $\mathrm{K}$ for $2 \mathrm{~h}$.

\section{2-1-4: Agricultural residues:}

Citrus branches and casuarina wood were used to produce charcoal using the tested kiln. Casuarina-tree blocks with mean dimensions of $5 \times 5 \times 20 \mathrm{~cm}$ and citrus branches with diameter range of $3-6 \mathrm{~cm}$ were used to produce the charcoal.

\section{2-2: Methods:}

The experimental tests were carried out at "Ezbet Amr" Village, "Ashmoon", Menoufia Governorate during the year of 2020.

\section{2-2-1: Tested parameters.}

The tested parameters of charcoal performance were:

1- Wood type: casuarina with constant moisture-content of $6.8 \%$ and citrus branches with constant moisture-content of $7 \%$ were tested.

2- Physical and chemicals properties of charcoal were measured using casuarina wood with moisture content of $6.8 \%$ and citrus branches with moisture content of $7 \%$ at all tested temperatures. 

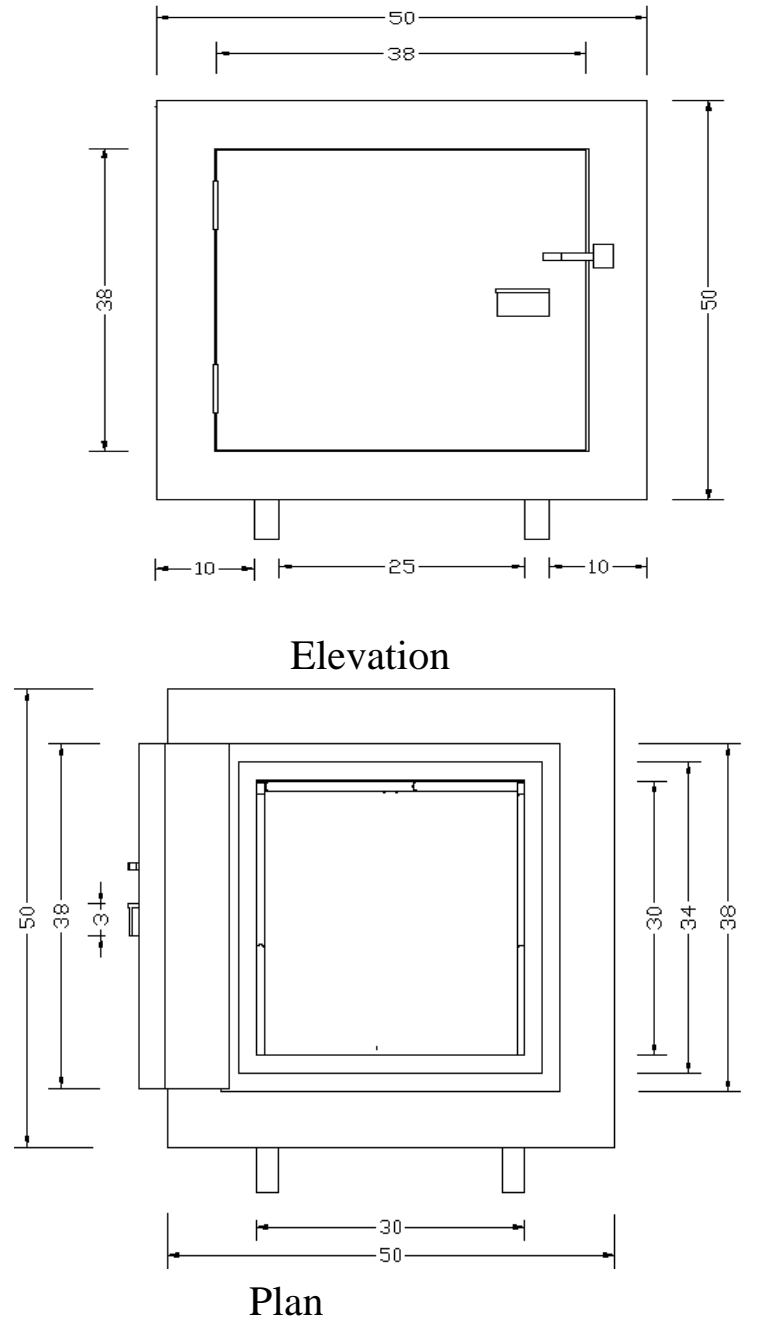

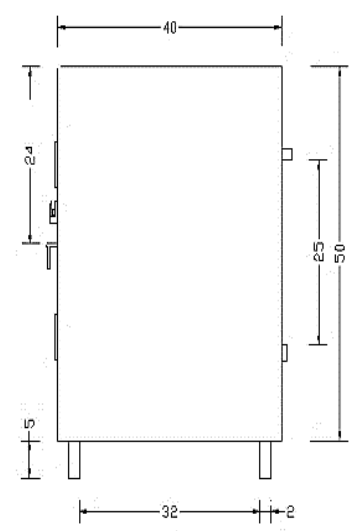

Said view

Fig. 2: Views of the ceramic oven.

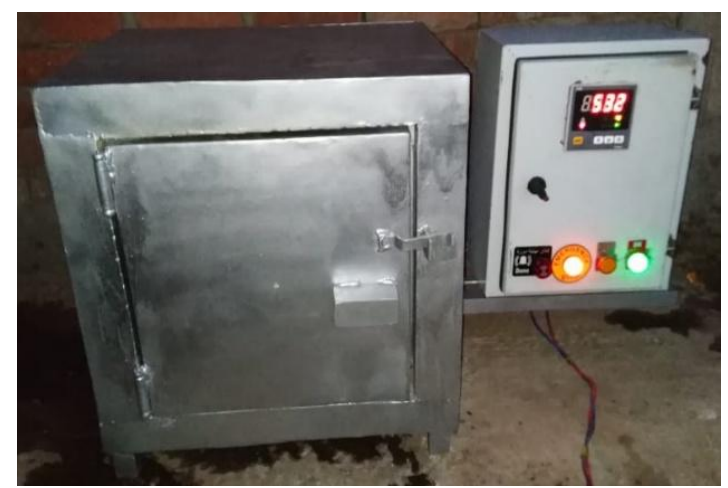

Fig. 3: Photograph of the ceramic oven.

\section{2-2-2: Measurements:}

\section{(a) Moisture content for charcoal.}

Charcoal samples were oven dried at $378.15 \mathrm{~K}$ for $2 \mathrm{~h}$ according to standard of "ASTM D1762-84 (1989). The samples were weighed before and after drying and the moisture, content was determined by using the following equation:

$$
\text { M. } \mathrm{C}_{\mathrm{CH}}=\frac{\mathrm{MCCHb}-\mathrm{MCHa}}{\mathrm{MCHa}} \times 100
$$

Where: M.C $\mathrm{CH}_{\mathrm{H}}$ : Moisture content for charcoal, \% (db), $\mathrm{MCH}_{\mathrm{a}}$ : Sample mass after drying, $\mathrm{g}$ and $\mathrm{MCH}_{\mathrm{b}:}$ Sample mass before drying, g. 


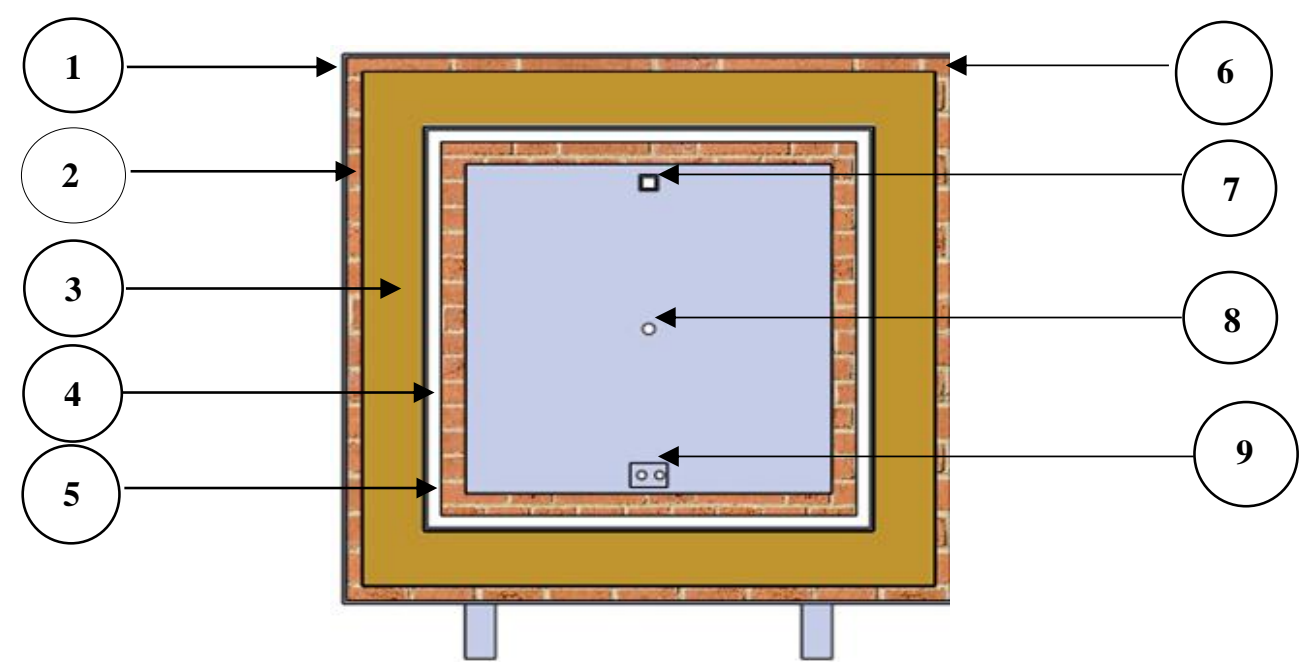

(1) Iron sheet, (2) layer of thermal brick, (3) layer of a rock wool, (4) iron sheet,

(5) layer of ceramic fiber, (6) layer of thermal brick, (7) ventilation hole, (8) sensor hole and (9) connection point heater cables.

Fig. 4: Isometric of the ceramic oven.

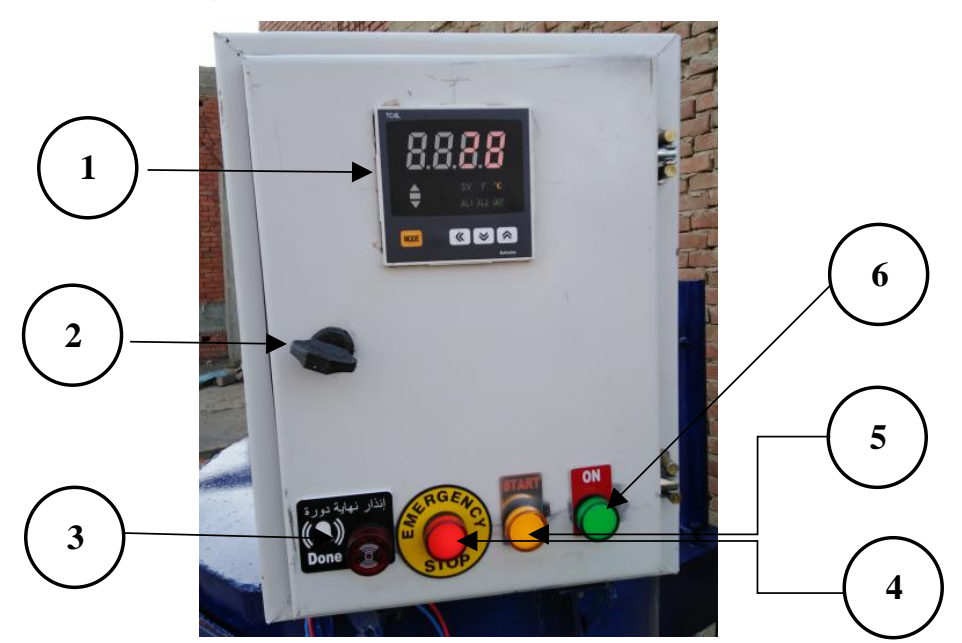

(1) Thermometer, (2) button, (3) alarm, (4) heater lamp, (5) motor lamp and (6) power lamp.

\section{(b) Bulk density of charcoal.}

Fig. 5: Photograph of the control unit.

The bulk density of the charcoal samples was determined by filling a container (measuring box) with charcoal and determining the bulk density by the following equation (BS ISO 23499:2013):

$$
\mathrm{p}_{\mathrm{CH}}=\frac{\mathrm{Ma}}{V} \times 100
$$

Where: pсH: Bulk density of the charcoal, g. $\mathrm{cm}^{-3}, \mathrm{M}_{\mathrm{a}}$ : Mass of the charcoal, $\mathrm{g}$ and $\mathrm{V}$ : Volume of the container, $\mathrm{cm}^{3}$.

\section{(c) Ash content.}

Ash content for charcoal was measured according standard of (ASTM D1762-84 (1989). Ash content is calculated according the following equation.

Ash content, $\%=\frac{\text { Maco-Macd }}{\text { Maco }} \times 100$

Where: $\mathrm{M}_{\mathrm{aco}}$ : Mass of dried sample of charcoal, $\mathrm{g}$ and $\mathrm{M}_{\mathrm{acd}}$ : Mass of sample after $4 \mathrm{~h}$ in furnace at $1023.15 \mathrm{~K}$. 
(d) Volatile matter.

Volatile matter for charcoal was measured according standard of “ASTM D1762-84 (1989)". Volatile matter is calculated according the following equation.

Volatile matter, $\%=\frac{\text { Mcho-Mchd }}{\text { Mchd }} \times 100$

Where: $\mathbf{M}_{\text {cho: }}$ Mass of dried sample of Charcoal, $g$ and $\mathbf{M}_{\text {chd }}$ : Volatile matter was extracted by pre-heating the specimen in a tube furnace for two minutes at $573.15 \mathrm{~K}$ then heating for three minutes at $773.15 \mathrm{~K}$ and for six minutes at $1223.15 \mathrm{~K}$. Volatile-matter content was calculated as a proportion of the oven-dry weight of the charcoal specimen.

(e) Fixed carbon.

Fixed carbon represents the quantity of carbon that can be burnt by a primary current of air drawn through the hot bed of a fuel (Moore and Johnson, 1999). The fixed carbon content of the samples was calculated according to (F A O .1985) using the following relation:

Fixed carbon content, $\%=100-\left(\mathrm{M} . \mathrm{C}_{\mathrm{CH}}+\mathrm{V} \mathrm{M}+\mathrm{A} \mathrm{C}\right)$

Where: M.C $\mathrm{CH}_{\mathrm{CH}}$ Moisture content, \%, V M: Volatile matte, \% and A C: Ash content, \%.

(f) Heating value.

Heating value " Calorific value " was calculated according to the following equation (Jayaraj et al., 2015):

C. V. $=2.326(147.6 \mathrm{FC}+144 \mathrm{VM})$

Where: C. V: Heating value, $\mathrm{kJ} \mathrm{kg}^{-1}$, F C: Fixed carbon, \% and VM: Volatile matter, $\%$.

\section{3- RESULTS AND DISCUSSION}

\section{3-1: Effect of kiln temperature and wood type on moisture-content of charcoal.}

Fig. 6 shows the effect of kiln temperature and wood type on moisture-content of charcoal.

The maximum moisture-content of $5.52 \%$ was obtained using casuarina wood at kiln temperature of $723.15 \mathrm{~K}$. Meanwhile, the minimum moisture-content of $1.28 \%$ was obtained using citrus branches at kiln temperature of $573.15 \mathrm{~K}$.

The increasing of moisture-content by increasing temperature is due to increasing absorbing the moisture from humidity. This may be explained by the fact that wood, like other lignocelluloses, is hygroscopic, with a relatively high affinity for water. In addition, the increasing of moisture-content of casuarina wood compared with citrus branches is due to the porosity of casuarina is higher than citrus branches according to (Fialho et al. 2020).

Charcoal fresh from an opened kiln contains very little moisture, usually less than $1 \%$. Absorption of moisture from the humidity of the air itself can bring the moisture content to about 5 to $10 \%$ (FAO, 2010). The maximum moisture-content of charcoal is $5 \%$ (ES: 69211/2009). In this investigation, casuarina charcoal moisture-content range of $2.36-4.38 \%$ was obtained using kiln temperature of range 573.15 - $673.15 \mathrm{~K}$. Meanwhile, citrus charcoal moisture-content range of 1.28 - $4.12 \%$ was obtained using kiln temperature range of 573.15 $723.15 \mathrm{~K}$.

Factors affecting moisture-content of charcoal were combined into prediction regressionequation under experiment and kiln conditions as follows:

$\begin{array}{lll}\mathrm{MC}_{\mathrm{S}}=0.29 \times 10^{-4} \times \mathrm{Tc} 2.122 & \left(\mathrm{R}^{2}=0.998\right) & \text { Casuarina charcoal } \\ \mathrm{MC}_{\mathrm{C}}=0.7528 \times 10^{-7} \times \mathrm{Tc} 2.926 & \left(\mathrm{R}^{2}=0.989\right) & \text { Citrus charcoal }\end{array}$

Where: $\mathrm{MC}_{\mathrm{S}}$ : Moisture-content for casuarina, $\% \mathrm{db}, \mathrm{MC}_{\mathrm{C}}$ : Moisture-content for citrus branches, $\% \mathrm{db}$ and $\mathrm{T}_{\mathrm{c}}$ : Temperature, $\mathrm{K}$ (ranged between $573.15-723.15 \mathrm{~K}$ ). 


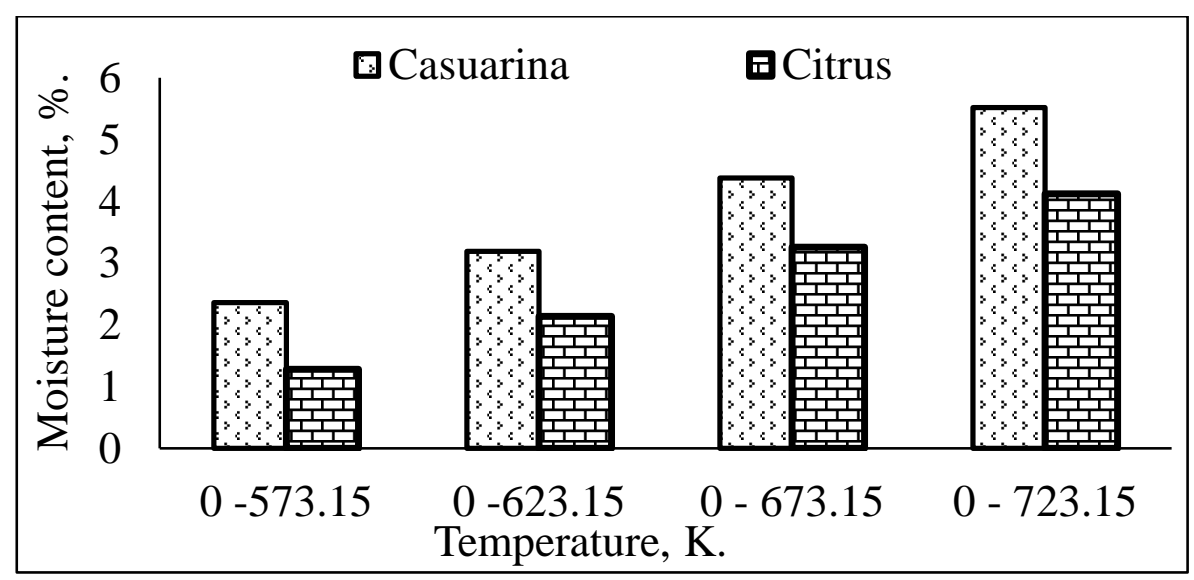

Fig. 6: Effect of kiln temperature and wood type on moisture-content for charcoal.

\section{3-2: Effect of kiln temperature and wood type on bulk density of charcoal.}

Fig. 7 shows the effect of kiln temperature and wood type on bulk density of charcoal. The results revealed that the bulk density of charcoal decreased by increasing kiln temperature for citrus branches and casuarina wood.

The maximum bulk density of charcoal of $409 \mathrm{~kg} \cdot \mathrm{m}^{-3}$ was obtained using citrus branches at kiln temperature of $573.15 \mathrm{~K}$. Furthermore, the minimum bulk density of charcoal of $264 \mathrm{~kg} . \mathrm{m}^{-3}$ was obtained using casuarina wood at kiln temperature of $723.15 \mathrm{~K}$.

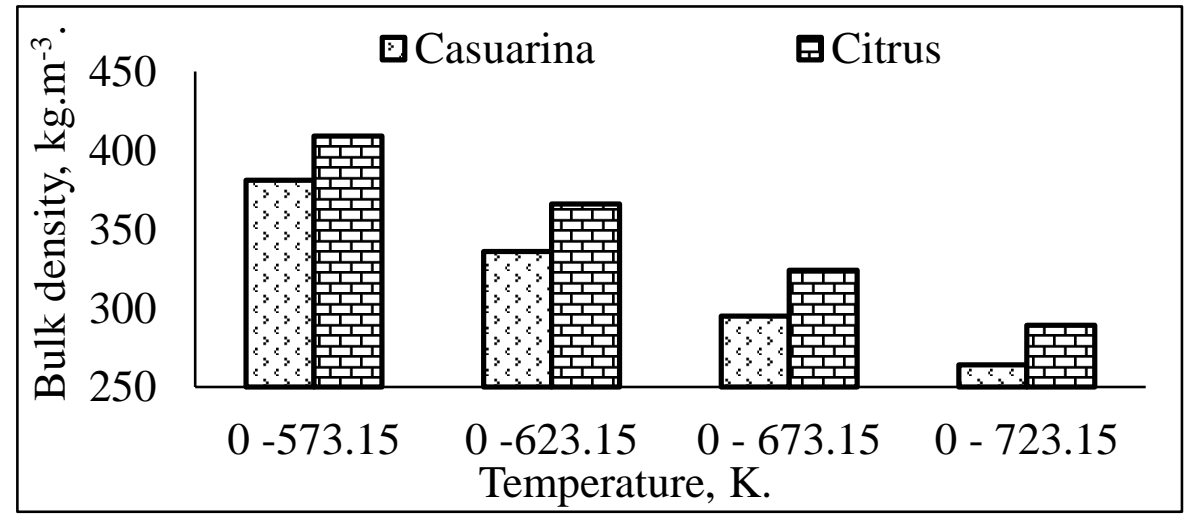

Fig. 7: Effect of kiln temperature and wood type on bulk density of charcoal.

The decreasing of bulk density by increasing temperature is due to decreasing charcoal mass. Increasing the density of citrus branches compared with casuarina wood is because of citrus branches have lignin content higher than casuarina wood. Increasing the density of citrus branches compared with casuarina wood may be because of citrus branches have lignin content higher than casuarina wood.

Date show that by increasing kiln temperature from 573.15 to $723.15 \mathrm{~K}$ the bulk density of citrus charcoal increased by $8.07 \%$ compared with casuarina charcoal at all tested wood type. Multiple regression analysis was carried out between charcoal bulk density data as a function of both kiln temperature and wood type. The following multiple prediction equations were obtained:
$\mathrm{Bd}_{\mathrm{S}}=68697.631 \times \mathrm{T}_{\mathrm{c}}{ }^{-0.90976}$
$\left(\mathrm{R}^{2}=0.998\right)$
Casuarina charcoal
$\mathrm{Bd}_{\mathrm{c}}==55268.35 \times \mathrm{T}_{\mathrm{c}}{ }^{-0.85859}$
$\left(\mathrm{R}^{2}=0.989\right)$
Citrus charcoal

Where: Bds: Moisture-content for casuarina, \%, Bd $\mathrm{C}_{\mathrm{C}}$ : Moisture-content for citrus branches, $\%$ and $\mathrm{T}_{\mathrm{c}}$ : Temperature, $\mathrm{K}$ (ranged between $573.15-723.15 \mathrm{~K}$ ). 


\section{3-3: Effect of kiln temperature and wood type on ash content of charcoal.}

Fig. 8 shows the effect of kiln temperature and wood type on ash content of charcoal. The results show that the ash content of charcoal decreased by increasing kiln temperature for citrus branches and casuarina wood.

The maximum ash-content of charcoal of $11.26 \%$ was obtained using casuarina wood at kiln temperature of $573.15 \mathrm{~K}$. Meanwhile, the minimum ash-content of charcoal of $4.95 \%$ was obtained using citrus branches at kiln temperature of $723.15 \mathrm{~K}$. The ash content of charcoal casuarina increased by $22.41 \%$ compared with charcoal of citrus branches.

Results show citrus charcoal ash-content of $4.95 \%$ was obtained using kiln temperature range of $723.15 \mathrm{~K}$. Meanwhile, the maximum ash content of charcoal is $6 \%$ according to (ES: 69211/2009). Date show that by increasing kiln temperature from 573.15 to $723.15 \mathrm{~K}$ the ash content decreased by $42.14 \%$ at all tested wood ash content.

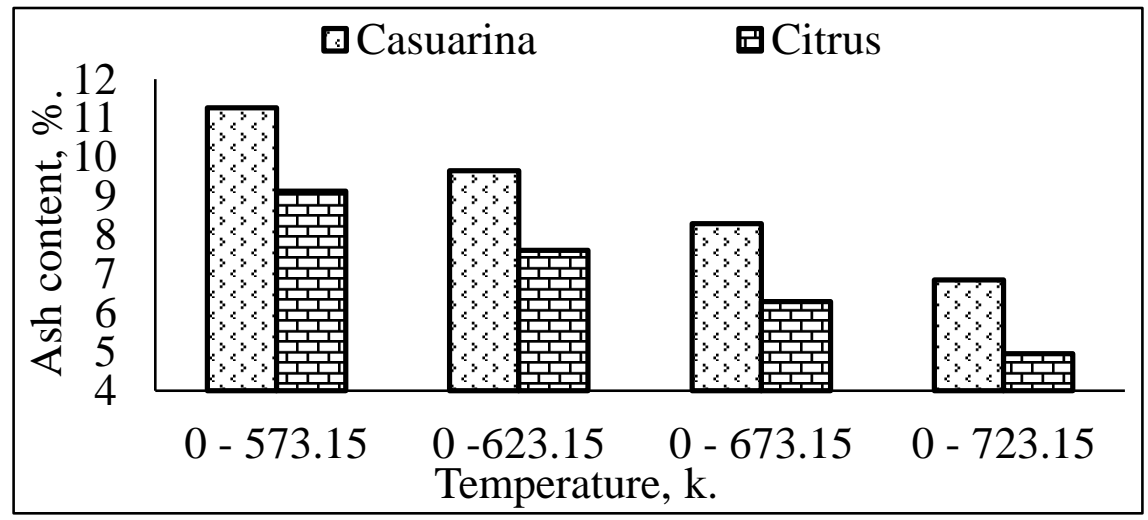

Fig. 8: Effect of kiln temperature and wood type on ash content of charcoal.

Multiple regression analysis was carried out between charcoal ash content data as a function of both kiln temperature and wood type. The following multiple prediction equations were obtained:

$\begin{array}{lll}\mathrm{Sh}_{\mathrm{S}}=11527.3067 \times \mathrm{T}_{\mathrm{c}}{ }^{-1.21221} & \left(\mathrm{R}^{2}=0.987\right) & \text { Casuarina } \\ \mathrm{Sh}_{\mathrm{C}}=5104.621 \times \mathrm{T}_{\mathrm{c}}{ }^{-1.48717} & \left(\mathrm{R}^{2}=0.984\right) & \text { Citrus branches }\end{array}$

Where: Shs: Ash content for casuarina, \%, Sh S $_{\mathrm{S}}$ Ash content for citrus branches, $\%$ and $\mathrm{T}_{\mathrm{c}}$ : Temperature, $\mathrm{K}$ (ranged between $573.15-723.15 \mathrm{~K}$ ).

\section{3-4: Effect of kiln temperature and wood type on volatile matter of charcoal.}

Fig. 9 show the effect of kin temperature and wood type on volatile matter of charcoal. The results show that the volatile matter of charcoal decreased by increasing kiln temperature for citrus branches and casuarina wood.

The maximum volatile matter of $21.25 \%$ was obtained using citrus charcoal at kiln temperature of $573.15 \mathrm{~K}$. Moreover, the minimum volatile matter of charcoal of $4.13 \%$ was obtained using casuarina charcoal at kiln temperature of $723.15 \mathrm{~K}$.

Data show that by increasing kiln temperature from 573.15 to $723.15 \mathrm{~K}$ the volatile matter decreased by $68.69 \%$ at all tested wood. Results show that volatile matter of casuarina charcoal of $4.13 \%$ was obtained using kiln temperature of $723.15^{\circ} \mathrm{K}$. Meanwhile, the maximum volatile matter of charcoal is $7 \%$ according to (ES: 6921-1/2009).

Decreased of volatile matter by increasing kiln temperature may be due to increasing loss of gases. Increased citrus-branches volatile matter compared with casuarina wood because of the citrus branches have more aromatic oils than casuarina wood. 


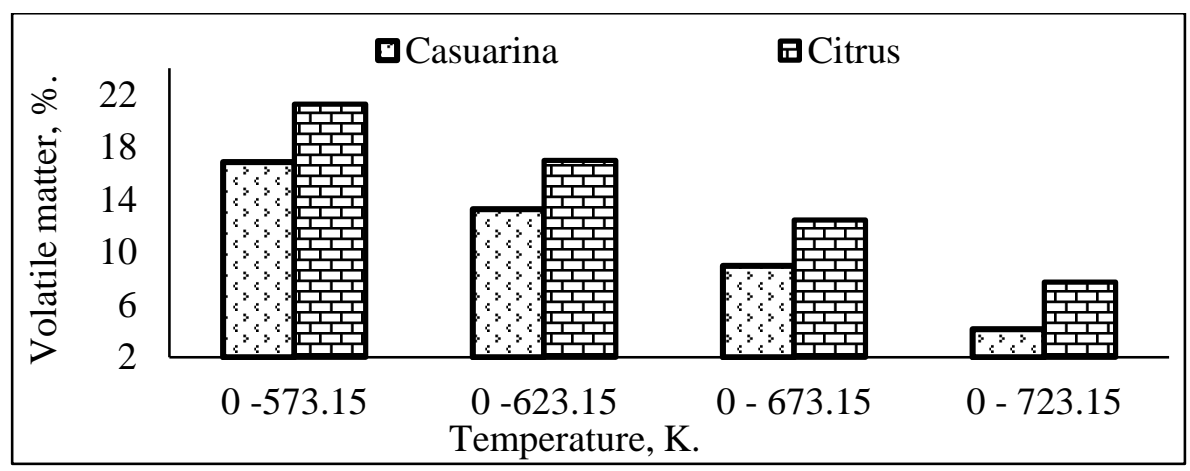

Fig. 9: Effect of kiln temperature and wood type on volatile matter of charcoal.

Factors affecting volatile matter of charcoal were combined into prediction regression-equation under experiment and kiln conditions as follows:
$\mathrm{VM}_{\mathrm{S}}=3.88 \times 10^{9} \times \mathrm{T}_{\mathrm{c}}{ }^{-3.351}$
$\left(\mathrm{R}^{2}=0.903\right)$
Casuarina
$\mathrm{VM}_{\mathrm{C}}=2.569 \times 10^{7} \times \mathrm{T}_{\mathrm{c}}{ }^{-2.445}$
$\left(\mathrm{R}^{2}=0.948\right)$
Citrus branches

Where: VMs: Volatile matter for casuarina, $\%, \mathrm{VM}_{\mathrm{C}}$ : Volatile matter for citrus branches, and $\mathrm{T}_{\mathrm{c}}$ : Temperature, $\mathrm{K}$ (ranged between $573.15-723.15 \mathrm{~K}$ ).

\section{3-5: Effect of kiln temperature and wood type on fixed carbon of charcoal.}

Fig 10 shows the effect of kiln temperature and wood type on fixed carbon of charcoal. The results show that the percentage of fixed carbon of charcoal increased by increasing kiln temperature for citrus branches and casuarina wood. In addition, the fixed carbon of citrus branches is higher than casuarina.

The maximum fixed carbon of charcoal of $84.81 \%$ was obtained using citrus branches at kiln temperature of $723.15 \mathrm{~K}$. Meanwhile, the minimum fixed carbon of charcoal of $65.13 \%$ was obtained using casuarina at kiln temperature of $573.15 \mathrm{~K}$.

The fixed carbon of charcoal citrus branches increased by $5.64 \%$ compared with charcoal of casuarina at all tested kiln temperature. Data show that by increasing kiln temperature from 573.15 to $723.15 \mathrm{~K}$ the fixed carbon increased by $18.36 \%$ at all tested woods. Antal and Gronli (2003) confirm these results.

Results show that citrus charcoal fixed carbon of $84.81 \%$ was obtained using kiln temperature of $723.15 \mathrm{~K}$. Meanwhile, the minimum fixed carbon of charcoal is $80 \%$ according to (ES: 6921-1/2009).

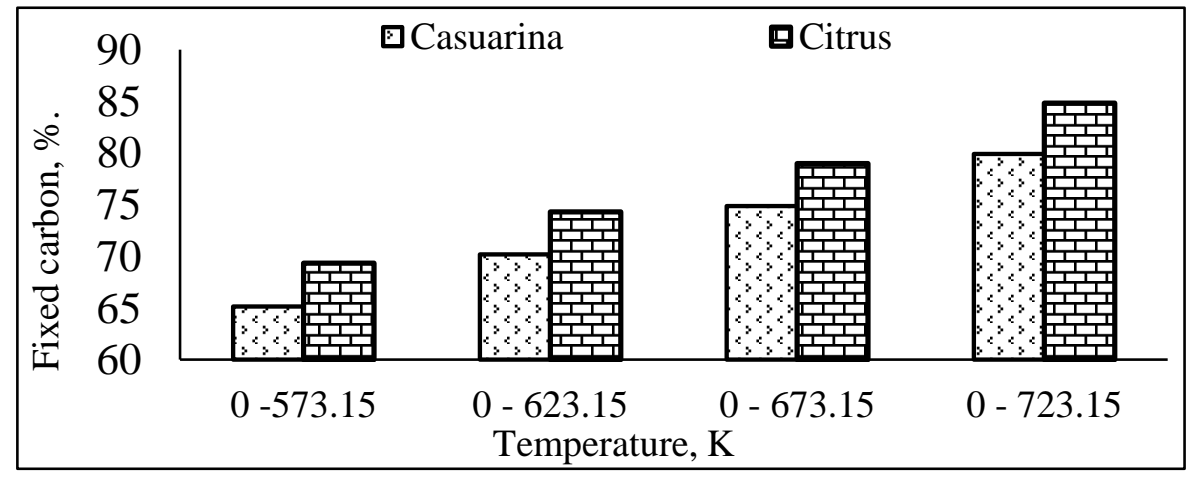

Fig. 10: Effect of kiln temperature and wood type on fixed carbon of charcoal.

Increased of fixed carbon of charcoal by increasing kiln temperature is due to decreasing of volatile matter and ash content of charcoal. On other hand, increased fixed carbon of citrusbranches compared with casuarina wood may be because of the citrus branches have more lignin. 
Factors affecting fixed carbon of charcoal were combined into prediction regression-equation under experiment and kiln conditions as follows:
$\mathrm{FC}_{\mathrm{S}}=3.717 \times \mathrm{T}_{\mathrm{c}}{ }^{0.5018}$
$\left(\mathrm{R}^{2}=0.999\right)$
$\left(\mathrm{R}^{2}=0.995\right)$
Casuarina
$\mathrm{FC}_{\mathrm{C}}=4.321 \times \mathrm{T}_{\mathrm{c}}{ }^{0.4907}$
Citrus branches

Where: FCs: Fixed carbon for casuarina, $\%, \mathrm{FC}_{\mathrm{C}}$ : Fixed carbon for citrus branches, $\%$ and $\mathrm{T}_{\mathrm{c}}$ : Temperature, $\mathrm{K}$ (ranged between $623.15-723.15 \mathrm{~K}$ ).

\section{3-6: Effect of kiln temperature and wood type on heating value of charcoal.}

Fig. 11 shows the effect of kiln temperature and wood type on heating value of charcoal. The results show that the heating value of charcoal increased by increasing kiln temperature for citrus branches and casuarina wood. In addition, the heating value of citrus branches is higher than casuarina charcoal.

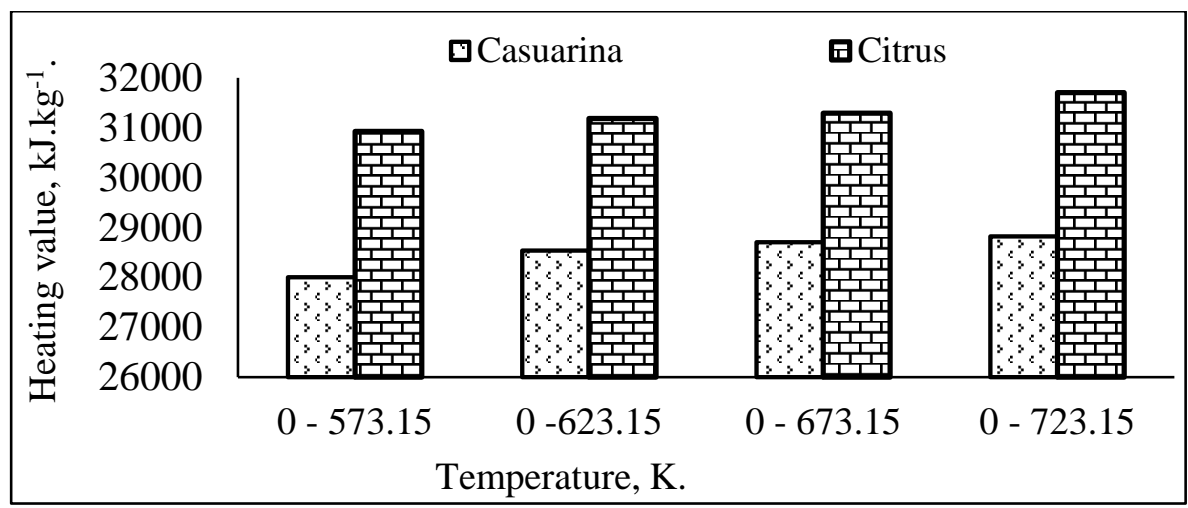

Fig. 11: Effect of kiln temperature and wood type on heating value of charcoal.

The maximum heating value of citrus charcoal of $31703 \mathrm{kj} \cdot \mathrm{kg}^{-1}$ was obtained at kiln temperature of $723.15 \mathrm{~K}$. Moreover, the minimum heating value of casuarina charcoal of $28004 \mathrm{kj} \cdot \mathrm{kg}^{-1}$ was obtained at kiln temperature of $573.15 \mathrm{~K}$. These results are confirmed Karkkainen (2007).

The heating value of charcoal citrus branches increased by $8.83 \%$ compared with charcoal of casuarina at all tested kiln temperatures. Date show that by increasing kiln temperature from 573.15 to $723.15 \mathrm{~K}$ the heating value increased by $2.63 \%$ at all tested woods.

Factors affecting heating value of charcoal were combined into prediction regression-equation under experiment and kiln conditions as follows:
$\mathrm{CV}_{\mathrm{S}}=2.30 \times 10^{3} \times \mathrm{T}_{\mathrm{c}}{ }^{0.069}$
$\left(\mathrm{R}^{2}=0.909\right)$
Casuarina
$\mathrm{CV}_{\mathrm{C}}=2.49 \times 10^{3} \times \mathrm{T}_{\mathrm{c}}{ }^{0.056}$
$\left(\mathrm{R}^{2}=0.931\right)$
Citrus branches

Where: $\mathrm{CV}_{\mathrm{S}}$ : Heating value for casuarina, $\%, \mathrm{CV}_{\mathrm{C}}$ : Heating value for citrus branches, $\%$ and $\mathrm{T}_{\mathrm{c}}$ : Temperature, $\mathrm{K}$ (ranged between $573.15-723.15 \mathrm{~K}$ ).

\section{CONCLUSION}

The optimum charcoal-quality was obtained at kiln temperature of $723.15 \mathrm{~K}$. The optimum charcoal quality were citrus charcoal moisture-content of $4.12 \%$, bulk density of $289 \mathrm{~kg} \cdot \mathrm{m}^{-3}$, ash-content of $3.95 \%$, volatile matter of $7.72 \%$, fixed carbon of $84.81 \%$ and heating value of $31703 \mathrm{kj} . \mathrm{kg}^{-1}$. Optimum results for casuarina-charcoal quality: moisture-content of $5.52 \%$, bulk density of $264 \mathrm{~kg} / \mathrm{m}^{3}$, ash-content of $6.84 \%$, volatile matter of $4.13 \%$, fixed carbon of 79.92 $\%$ and heating value of $28821 \mathrm{kj} \cdot \mathrm{kg}^{-1}$.

\section{REFFERENCES}

Antal, M. J and M. Gronli (2003). The art, science and technology of charcoal production. Industrial and Engineering Chemistry Research. 42(8):1619-1640. 
AOAC, (1990). Association official Analytical chemists. $15^{\text {th }}$ edn. Washington Dc, U.S.A.

ASAE, (1998). ASAE S353 DEC97 Standards. Moisture measurement-meat and products. Adopted and published by ASAE 1998, St. Josebh, MI: ASAE. $45^{\text {th }}$ Edition P552.

ASTM, (1989). American Society for Testing and Materials. Standard Test Methods for chemical analysis of charcoal. D 1762-84.

Bapat, D.W.; S. V. Kulkarni and V. P. Bhandarkar (1997). Design and operating experience on fluidized bed boiler burning biomass fuels with high alkali ash. In: Preto FDS, editor. Proceedings of the 14th international conference on fluidized bed combustion. New York: Vancouver ASME.

BS ISO 23499. (2013). British Standard / International Organization for Standardization. Coal. Determination of bulk density for the use in charging of coke ovens.

ES: 6921-1. (2009).Egypt standards. Charcoal. Part1: general requirement for charcoal used as fuels.

FAO, (1985). Food and Agriculture Organization of the United Nations Forestry Simple technologies for charcoal making.

FAO, (2010). Food and Agriculture Organization of the United Nations Principles, criteria and indicators for sustainable charcoal production, criteria and indicators for sustainable wood fuels, P: 69-80.

Fialho, L.; A. Márcia.; D. B. Donato and A. O. Carneiro (2020). Impact of Wood Moisture in Charcoal Production and Quality. Floresta e Ambiente 27(1): P: 2-8.

Gomaa, H. A.; S. Steele and Y. A. Hamdy. (2011). Charcoal Industries Egypt. Food and Agriculture Organization of the United Nations Regional Office for the Near East -Cairo.

Hosier, R. H. (1993)."Charcoal Production and Environmental Degradation: Environmental History, Selective Harvesting, and Post-Harvest Management." Energy Policy 21(5): 491509.

Jayaraj, V.; B. Prakash.; G. Sasikumar, and L. Vijayabaskar. (2015). Characterization of Straw and Paper Pulp Blended Sawdust Briquettes.International Journal of Research in Engineering Science and Technology. vol 1.(4) :1- 6 .

John, K.; N. R. Bashirelahi and A. Mark (2017). "Charcoal and charcoal-based dentifrices: A literature review". Journal of the American Dental Association. 148(9): 661-670.

Kaale, B. K. (2005). Baseline study on biomass energy conservation in Tanzania. SADC programmer for Biomass Energy Conservation (Pro BEC) Report.355.

Karkkainen, M. (2007). Puun rakenne ja ominaisuudet. Metsakustannus. Helsinki: 245-247.

Keita, J. D. (2010). "Wood or Charcoal - which is better" Unasylva - No. 157-158 - Small-scale forest enterprises. Vol. 39, 1987/3 and 4, an international journal of forestry and forest industries, FAO - Food and Agriculture Organization of the United Nations, Rome.

Moore, W and D. Johnson (1999). Procedure for the Chemical Analysis of Wood and Wood Products, Madison WL: US. Forest Products Laboratory, Department of Agriculture.

Orabi, M. A.; 1. A. H. Bahnasawy.; S. A. Ali.; T. H. Ashour and I. Yehia. (2020). Development of environment friendly kilns for production of charcoal. Misr J. Ag. Eng., 37 (3): 313 - 324

Vandam, J. (2014). The Charcoal Transition: Greening the Charcoal Value Chain to Mitigate Climate Change and Improve Local Livelihoods, FAO: Rome, Italy. 


\section{تأثير درجة حرارة الفرن ونوع الخشب على جودة الفحم النباتي}

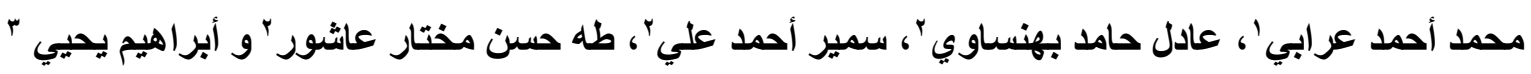

' باحث مساعد ـ قسم بحوث نظم ميكنة العمليات الزر اعية ـ معهد بحوث الهندسة الزر اعية ـ الجيزة ـ مصر.

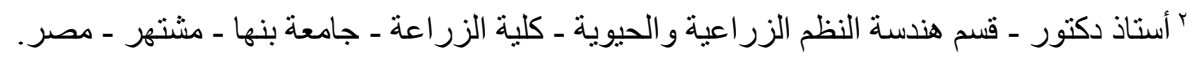

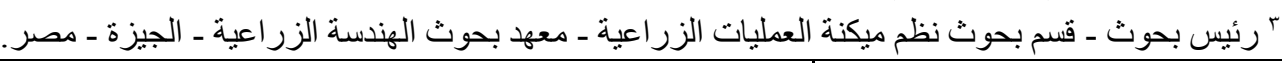

الملخص العربيى

يهدف البحث الى دراسة تأثير كلا من درجة الحرارة ونوع الخشب المستخدم فى أنتاج الفحم

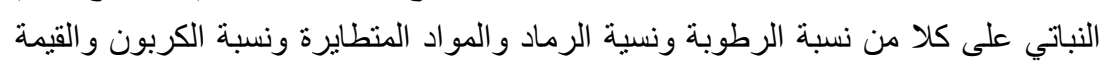

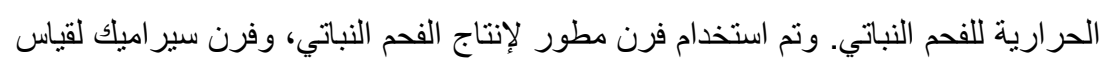

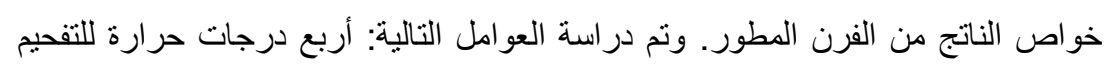

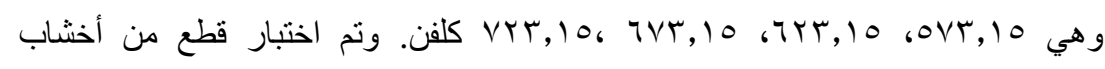

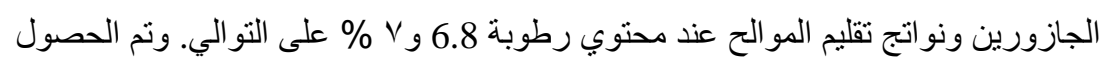

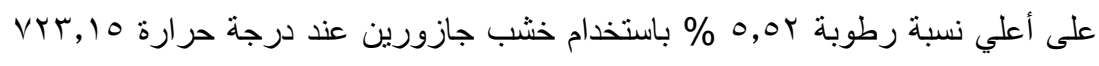

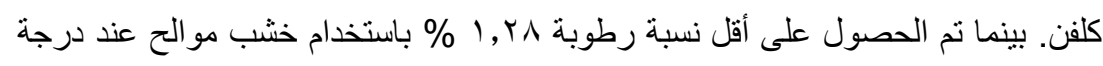

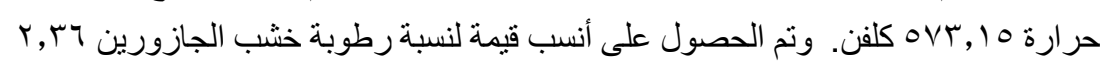
-

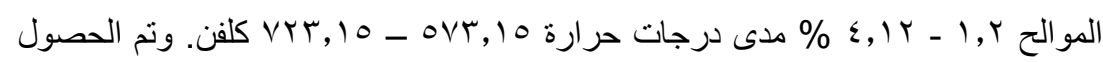

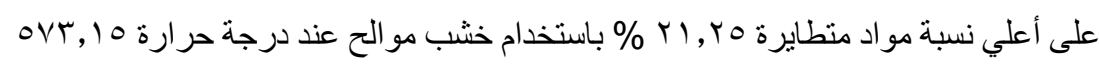

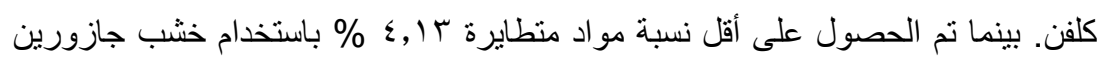

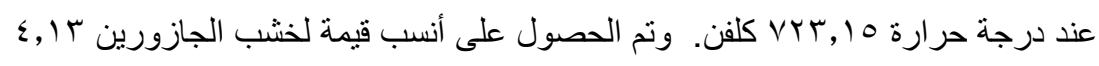

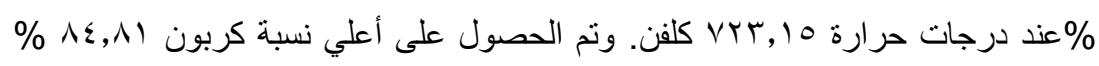

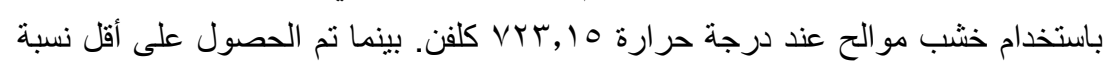

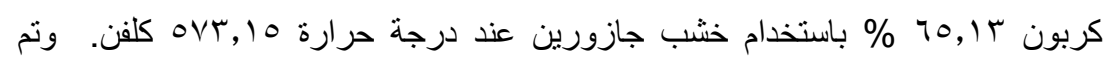

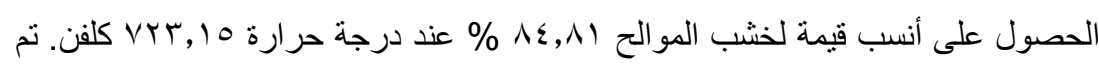

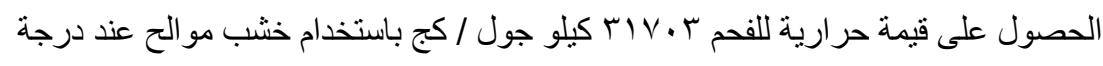

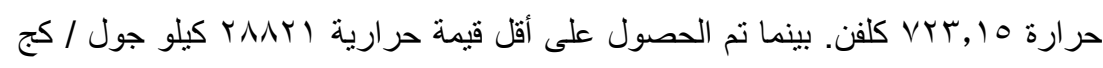

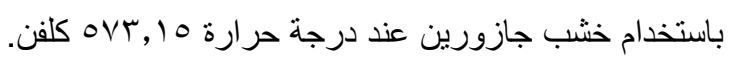

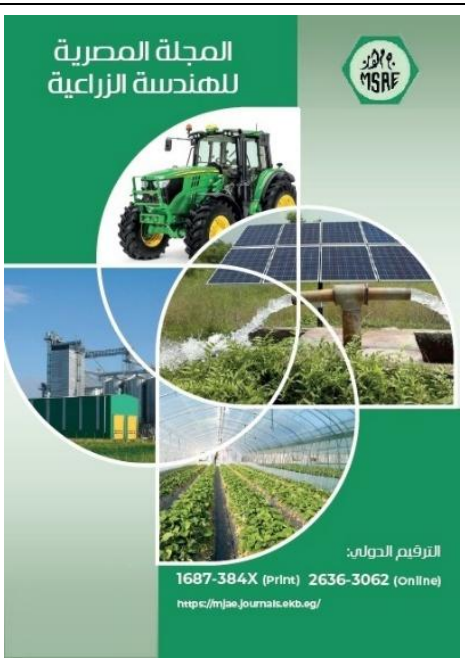

(C) المجلة المصرية للهندسة الزراعية

الكلمات المفتاحية: التفحيم، جوده الفحم، رطوبة الخشب، التشب،

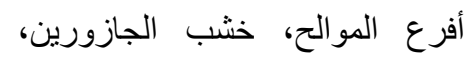
معالجة الانبعاثات أمرات 